\title{
Influence of intracellular toxin concentrations on cylindrospermopsin bioaccumulation in a freshwater gastropod (Melanoides tuberculata)
}

\author{
Authors: S. H. White*1, L. J. Duivenvoorden ${ }^{1}$, L. D. Fabbro ${ }^{1}$, G. K. Eaglesham ${ }^{2}$ \\ *Corresponding author: s.white@cqu.edu.au, PH +61 (0)7 4930 9647; \\ FAX +61 (0)7 49309209
}

Affiliations ${ }^{1}$ Freshwater Ecology Group, Centre for Environmental Management, Central Queensland University, Rockhampton, QLD 4701.

${ }^{2}$ Queensland Health Scientific Services, Coopers Plains, QLD 4109

\section{Author contact details:}

S. White:

L. Duivenvoorden:

L. Fabbro:

20

G. Eaglesham
C/- Biological and Environmental Sciences, Building 6, Central Queensland University, Bruce Highway, Rockhampton, QLD 4702 Australia as for $\mathrm{S}$. White (above) C/- Centre for Environmental Management, Building 9. Central Queensland University, Bruce Highway, Rockhampton, QLD 4702 Australia Queensland Health Scientific Services 39 Kessels Rd, Coopers Plains, QLD, 4109 Australia.

\section{Abstract}

Scant information is available regarding the bioaccumulation of cylindrospermopsin $(\mathrm{CYN})$ in aquatic organisms, particularly in invertebrates. This study examined toxin bioconcentration and bioaccumulation in the aquatic snail, Melanoides tuberculata, 30 following exposure to freeze-thawed whole cell extracts and a live Cylindrospermopsis raciborskii culture containing CYN. Both bioconcentration and bioaccumulation were evident, but exposure to toxin in the freeze-thawed solutions resulted in minor tissue contamination in comparison that resulting from live $C$. raciborskii exposure. Thus, whilst CYN uptake resulted from both extracellular and intracellular exposures, the availability of intracellular toxin was critical in affecting tissue CYN values. M. tuberculata did not bioconcentrate CYN into the shell. Bioaccumulation of the analog deoxy-CYN was also recorded. Knowledge of 
intracellular toxin concentrations may be critical in evaluating the bioaccumulation, ecological and human health risks associated with contaminated systems.

Keywords: Cylindrospermopsis raciborskii, bioaccumulation, bioconcentration, bluegreen algae, cyanobacteria, deoxy-cylindrospermopsin.

\section{Introduction}

Cylindrospermopsin $(\mathrm{CYN})$ is a protein-synthesis inhibiting algal toxin (Terao et al. 1994) produced by several cyanoprokaryote species including Cylindrospermopsis raciborskii (in Australia, Thailand, Hungary, New Zealand and the United States), Umezakia natans (Japan), Aphanizomenon ovalisporum (Israel and Australia), Anabaena bergii var limnetica and Raphidiopsis curvata (Ohtani et al. 1992; Harada et al. 1994; Shaw et al. 1999; Schembrii et al. 2001; Stirling \& Quilliam 2001; Li et al. 2001a). Highly toxic CYN-producing blooms appear to be increasing globally (Padisák 1997; Briand et al. 2004). Hence, understanding the range of effects associated with CYN exposure, including the potential for tissue contamination, is becoming increasingly important.

20 Bioaccumulation, simply defined, is a process whereby uptake of a toxicant results in tissue concentrations exceeding those present in the surrounding environment (Burkhard et al. 2003). In the case of algal toxins, uptake may occur from extracellular, intracellular or tissue-bound toxin fractions. Thus, accumulation can be further separated into bioconcentration, where uptake results exclusively from dissolved toxins; and bioaccumulation, where uptake may result from both dissolved and cellular toxins (Mackay \& Fraser 2000; Voutsas et al. 2002; van der Oost et al. 2003). 
The primary modes of CYN uptake are unknown. The relative abundance of intracellular and extracellular toxin fractions, including spatial and temporal variation, depends largely on bloom speciation and the age of a toxic bloom. This may be critical, since fraction bioavailability is inextricably linked to available toxin uptake routes. Recently, this concept has been investigated as a possible means of predicting and managing bioaccumulation risk for aquatic organisms living in contaminated waters (White et al. 2005). However, field and experimental research data is needed to further develop this predictive management framework. To date, only two studies have examined bioaccumulation of CYN in aquatic organisms (Saker \& Eaglesham 10 1999; Saker et al. 2004). Cylindrospermopsin has also been recorded from the cladoceran Daphnia magna (Nogueira et al. 2004a). In the latter, however, bioaccumulation was not present, since reported bioaccumulation factors (tissue toxin concentrations divided by available toxin) were $<1$.

This study examines accumulation of CYN and its analog, deoxy-CYN, in the freshwater gastropod, Melanoides tuberculata. Since gastropods are grazer species, multiple methods of CYN uptake are possible. Herbivorous species may ingest cellular toxins by grazing (intentionally or accidentally) on toxic blue-green algae. Snails may also be vulnerable to dissolved transdermal uptake as a result of their 20 submerged habit, and consequent prolonged contact with dissolved toxins. Several gastropod species are already known to bioaccumulate microcystin (Kotak et al. 1996; Zurawell 2001; Yokoyama \& Park 2002; Ozawa et al. 2003; Yokoyama \& Park 2003), but studies have not examined CYN bioaccumulation.

\section{Materials and Methods}


Melanoides tuberculata (Müller, 1774) is an introduced Asian prosobranch snail typically found in stagnant or slow-flowing waters (Dillon 2000). The species is relatively common in central Queensland waterways. M. tuberculata were collected from Moores Ck (Rockhampton, Queensland). A subsample of Moores Ck water collected at the site was subsequently shown to have no CYN present. Specimens were cultured in a large plastic tub filled with Moores $\mathrm{Ck}$ water and housed in a controlled climate room $\left(24 \pm 2^{0} \mathrm{C}\right)$ under 12:12 light:dark photoperiod. Snails were provided mixed green algae obtained from the collection site. Snail species confirmation was provided by Dr. Winston Ponder (Australian Museum, Sydney).

\subsection{Bioconcentration trials}

Bioconcentration was defined as the uptake of toxins from an exclusively extracellular source. Two trials examined CYN bioconcentration by exposing M. tuberculata to double freeze-thawed C. raciborskii whole cell extracts containing extracellular CYN. Treatments included controls plus five CYN concentrations at 25, 50, 100, 200 and $400 \mu \mathrm{g} \mathrm{L}^{-1}$. Test solutions $(200 \mathrm{~mL}$ volume) were prepared by diluting cultures of $C$. raciborskii (strain CQU FR001) of known toxicity to the desired test concentrations. In the first trial, the control and dilution waters used were filtered, aged, non-sterile tap water. Control and dilution waters in the second definitive trial were filtered

20 (Whatman GF/F glass microfibre) creek water obtained from the specimen collection site. All solutions, including controls, were replenished at two-day intervals throughout both trials to ensure constant CYN concentrations.

Trials were conducted under 12:12 L:D photoperiod regime $\left(80 \mu \mathrm{mol}\right.$ photon $\left.\mathrm{m}^{-2} \mathrm{~s}^{-1}\right)$. Test vessels were rectangular glass dishes with glass lids. Stainless steel mesh (Termi- 
mesh commercial-grade termite barrier) rectangles were cut and positioned at the surface to prevent snails escaping exposure to the test solutions. Small holes were punched through the mesh to accommodate aerators. Test chambers were randomly arranged and half-submersed in a water bath at $26.5 \pm 1.0{ }^{\circ} \mathrm{C}$. Water was kept well circulated by the use of Thermoline temperature regulation and water circulation devices. Water temperatures were recorded half-hourly using StowAway TidBit DataLoggers. Chamber aeration was provided by a HiBlow electric air compressor (Sakuragawa Pty Ltd, Japan).

10 Water quality data was collected at $48 \mathrm{~h}$ intervals, including measurements of conductivity (TPS LC84); pH (TPS 80A); dissolved oxygen (TPS WP-82Y) and total ammonia (Aquasonic or Aquarium Pharmaceuticals Inc., freshwater total ammonia salicylate test kits). Water hardness and alkalinity of the control / dilution water was measured from $150 \mathrm{~mL}$ filtered subsamples $(0.45 \mu \mathrm{m}$ Millipore nylon filter $)$ and determined using atomic absorption spectroscopy and alkalinity titrations.

Snails were not fed during the experimental period since toxin adsorption to food sources may have influenced the bioavailability of extracellular CYN. For example, snails may have been able to graze on adsorbed toxin, even though it was 20 extracellular. Minimizing food sources also reduced faecal matter, which may otherwise have decreased dissolved oxygen concentrations and hence the biological activity of some materials (ASTM 2003). Similarly long exposure periods without food have been used successfully by other authors (Lajtner et al. 1996; Klobucar et al. 1997). 
Trials commenced by randomly assigning three snails per flask. Snails were harvested ( $n=$ three flasks per treatment) on days seven and fourteen, euthanized by freezing and stored frozen until CYN analyses were carried out. Since trial one differed from all other experiments by the use of tap water in the controls, tissues from selected snails only were analysed for CYN in this trial. All snail specimens were analysed in the second (and third) trials.

When snails were harvested on day seven of the first definitive trial, shells were reserved during dissection to determine the concentration of CYN associated with the

10 shell component. Shells were pooled within treatment groups $(n=9$ shells per treatment), weighed (fresh weight) and frozen (unrinsed), before thawing and macerating into fine slurry using a glass mortar and pestle with $2 \mathrm{~mL}$ of Milli-Q water. The slurry was washed into centrifuge tubes and stored frozen until toxin analyses were carried out.

\subsection{Bioaccumulation trial}

Bioaccumulation was defined as toxin uptake resulting from both intracellular and extracellular sources. One trial examined the bioaccumulation of toxin during exposure to a live C. raciborskii culture. Test conditions were as described in the 20 extracellular trials, with the exception of the treatment solutions. These were prepared by pooling several one-litre $C$. raciborskii cultures into a fish tank on the day prior to trial commencement. Treatments were prepared by thoroughly mixing the tank culture with a metal spoon, subsampling and diluting to test concentrations of $10 \%, 20 \%$, $30 \%, 40 \%$ and $50 \%$, again using filtered creek water. Controls were filtered creek water only. 
Total $\left(\mathrm{CYN}_{\mathrm{TOT}}\right)$, intracellular $\left(\mathrm{CYN}_{\mathrm{INC}}\right)$ and extracellular $\left(\mathrm{CYN}_{\mathrm{EXC}}\right)$ toxin fractions were monitored closely throughout the trial. On day zero, and every $48 \mathrm{~h}$ thereafter, two $50 \mathrm{~mL}$ subsamples were collected from the source culture (tank), and two subsamples per treatment concentration (pooled sample of all replicates within a given treatment). For each pair, one sample was filtered (Whatman GF/F glass microfibre) and frozen for determination of $\mathrm{CYN}_{\mathrm{EXC}}$; the second was frozen without filtering for determination of $\mathrm{CYN}_{\mathrm{TOT}}$ (intracellular plus extracellular fractions). Total CYN only was determined from controls since no CYN was expected to be present. Variability within treatment replicates was also tested on random samples.

C. raciborskii cell concentrations were monitored in selected treatments and the source culture by periodically collecting $10 \mathrm{~mL}$ aliquots and preserving with Lugol's iodine. Later, duplicate trichome counts were performed using the Sedgewick-Rafter counting chamber method: each chamber was counted for a total of 25 squares or 100 trichomes. Trichome counts were converted to approximate cell counts by dividing average trichome length $(n=200$ trichomes; from control and various experimental treatments) by the known cell length of C. raciborskii strain FR001 in culture (Fabbro et al. 2001). Duplicate counts were averaged and CYN cell quotas calculated from known $\mathrm{CYN}_{\mathrm{TOT}}$ and $\mathrm{CYN}_{\mathrm{INC}}$ concentrations.

\subsection{Toxin analyses}

Specimens were thawed and the shell manually dissected from the soft tissues. Tissues were rinsed in distilled water and placed in a centrifuge tube, freeze-dried (approximately $24-48 \mathrm{~h}$, Virtis Sentry freeze-drier with Alcatel vacuum pump) and brought to room temperature before being reweighed. Tissues were then homogenised 
in Milli-Q water (Ultraturrax; 24,000 rpm for approximately one minute) and immediately frozen. Samples were sent to Queensland Health Scientific Services for analysis of CYN and deoxy-CYN concentration. Frozen samples were thawed, centrifuged at $3000 \mathrm{rpm}$ and the supernatant filtered using 0.45 micron syringe filters (Millex HV, Millipore Corp., Bedford, MA). Detection of free (non-bound) toxins was achieved via high performance liquid chromatography / tandem mass spectrometry, using an AB/Sciex API 300 mass spectrometer (Applied Biosystems, Concord, Ontario, Canada) equipped with a turbo-ionspray interface coupled to a Shimadzu SCL-10Avp HPLC system (Kyoto, Japan) (Eaglesham et al. 1999; Norris

10 et al. 1999). This technique has limit of detection $\leq 3.0 \mathrm{ng}$ per $5 \mathrm{~mL}$ sample (approximately equivalent to $0.5 \mu \mathrm{g} \mathrm{L}^{-1}$ ) for both CYN and deoxy-CYN. Spike recoveries averaged $87.5 \%$ at concentrations between 1.8 and $5.7 \mu \mathrm{g} \mathrm{L}{ }^{-1}(n=4)$.

\section{Results}

\subsection{Water quality and toxin concentrations}

Oxygen saturation of the test solutions generally remained $\geq 80 \%$ saturation; no gross changes in $\mathrm{pH}$ or conductivity occurred either within or between treatments (Table 1). Total ammonia concentrations also remained $\leq 1.0 \mathrm{ppm}$, excepting some $400 \mu \mathrm{g} \mathrm{L}^{-1}$ treatments in the extracellular trials. Measured CYN concentrations were generally at or above nominal test concentrations in extracellular trials (Table 2). In the live exposure trial, the average toxin concentration in the source culture was $659 \mu \mathrm{g} \mathrm{L}^{-1}$, whilst concentrations for the control and culture treatments were 1, 91, 167, 223, 294 and $406 \mu \mathrm{g} \mathrm{L}^{-1}$, respectively (Table 3). Maximum and minimum CYN exposure concentrations were therefore easily comparable with the nominal test values used in the extracellular trials $\left(0-400 \mu \mathrm{g} \mathrm{L}^{-1}\right)$. Toxin was detected in one control sample only 
(Table 3). Extracellular toxin represented between $72-81 \%$ of total CYN (Figure 1B, Table 3). Average deoxy-CYN concentrations ranged between $3-12 \mu g \mathrm{~L}^{-1}$ (controls excluded), or $1.8-3.3 \%$ deoxy-CYN relative to total CYN (Table 3 ).

Approximate toxin quotas $\left(\mathrm{Q}_{\mathrm{CYN}}\right)$ for C. raciborskii cells were calculated by dividing $\mathrm{CYN}_{\text {INC }}$ concentrations by cell count data. In the source culture, average $\mathrm{Q}_{\mathrm{CYN}}$ was $0.09 \mathrm{pg}$ cell $^{-1}$, whilst experimental treatments recorded an average $\mathrm{Q}_{\mathrm{CYN}}$ of $0.21 \mathrm{pg}$ cell $^{-1}$ (Table 4). However, if calculated from $\mathrm{CYN}_{\mathrm{TOT}}$ concentrations (intracellular plus extracellular toxin), $\mathrm{Q}_{\mathrm{CYN}}$ values were approximately four- to five-fold higher

10 (Table 4). Too few samples were taken to identify trends in $\mathrm{Q}_{\mathrm{CYN}}$ 's over the experimental period.

\subsection{Toxin in the shell}

Toxin deposition into the shell appeared to be generally dose-dependant (Figure 2). However, the bioconcentration factor (BCF; calculated as tissue toxin $\left(\mu \mathrm{g} \mathrm{kg}{ }^{-1}\right.$ wet weight) divided by exposure concentrations $\left(\mu \mathrm{g} \mathrm{L}^{-1}\right)$ ) averaged 0.12 (controls excluded), indicating no bioconcentration.

\subsection{CYN bioconcentration and bioaccumulation}

CYN concentrations in M. tuberculata varied greatly (Figure 3A-C). Maximum tissue concentrations corresponded with highest exposure concentrations $\left(400 \mu \mathrm{g} \mathrm{L}^{-1}\right)$ and longest exposure periods (fourteen days) (Figure 3A, B). Considerable differences in toxin concentrations were recorded from M. tuberculata the first and second definitive trials, despite both trials using the same exposure regime (Figure $3 \mathrm{~A}, \mathrm{~B}$ ). 
Tissue toxin concentrations were dramatically increased in the live culture trial compared with the whole-cell extract trials. Whilst the effect of exposure concentrations was relatively weak, increasing the exposure time from seven to fourteen days typically resulted in tissue CYN values being almost doubled (Figure 3C). Toxin concentrations were also more variable than the second definitive trial (Table 5).

A strong, positive correlation was evident between tissue CYN concentrations and CYN exposure concentrations (total or extracellular) in all trials (Table 6). In the live 10 trial, tissue toxin concentrations were significantly positively correlated with total $\mathrm{CYN}_{\mathrm{TOT}}, \mathrm{CYN}_{\mathrm{INC}}$ and $\mathrm{CYN}_{\mathrm{EXC}}$, and the ratio of intracellular to extracellular toxin. Exposure time was significantly positively correlated with absolute tissue toxin values in the live exposure trial only (Table 6).

Extracellular CYN exposure resulted in bioconcentration only in definitive trial one, when exposures were $\geq 200 \mu \mathrm{g} \mathrm{L}^{-1}$ (Table 7). The maximum BCF was 1.48 , recorded after fourteen days exposure to $400 \mu \mathrm{g} \mathrm{L} \mathrm{L}^{-1}$. Generally, increased exposure times and exposure concentrations resulted in higher BCFs (Figure 4A). Bioaccumulation values were strikingly different in the live exposure trial. Every treatment (excluding 20 controls) recorded bioaccumulation, with bioaccumulation factors (BAFs) being $>100$, especially in the second week of exposure (Table 7). Again, high BAFs corresponded with increased exposure concentration and exposure time (Figure 4B). However, CYN treatment concentration significantly influenced the BCF of $M$. tuberculata only in the first extracellular trial (Table 8). Increasing exposure time significantly increased BAF values in the live exposure trial (Table 8). 


\subsection{Deoxy-CYN bioconcentration and bioaccumulation}

Deoxy-CYN concentrations were analysed in trials two (extracellular exposure) and three (live exposure) only. Overall, average tissue deoxy-CYN concentrations were far lower than CYN concentrations, peaking at 7,113 $\mu \mathrm{g} \mathrm{kg}^{-1}$ (dry weight) during the live culture trial (Figure 5A, B). Bioconcentration factors could not be calculated in the extracellular trial since deoxy-CYN exposure concentrations were unknown. In the live trial, BAFs ranged from 20.4 to 249.3 (Table 9). Increased BAFs corresponded with increased exposure times (Figure 6), in similarity to the CYN

10 bioaccumulation results. However, the BAFs of CYN and deoxy-CYN were significantly different in the live trial ( $p>0.050$; one-way ANOVA), with average total deoxy-CYN BAFs being higher than those for CYN (85.4 and 72.3, respectively). Both CYN treatment concentration and exposure time were significantly correlated with deoxy-CYN concentrations in the tissues (Table 10). However, only exposure time was significantly correlated with deoxy-CYN bioaccumulation factors.

\section{Discussion}

\subsection{Water quality}

Differences in the conductivity, alkalinity and hardness of dilution waters reflected rain periods that occurred between specimen (and hence control water) collections. Since M. tuberculata thrives in these conditions naturally, such variations are considered to have had minimal influence on the snails. Elevated total ammonia concentrations may be associated with large quantities of faecal matter.

\subsection{CYN, deoxy-CYN and cell concentrations}


Deoxy-CYN concentrations relative to CYN concentrations ranged widely, averaging $29 \%$ (second trial) to just $2.5 \%$ (third trial) (Tables 2, 3). The production of deoxyCYN may depend on at least three factors: the species and/or strain responsible for production; culture age; and the makeup of culturing media, particularly regarding to nitrogen availability. Deoxy-CYN production has been reported at $27-200 \%$ the quantity of CYN for an Australian C. raciborskii grown in Jaworski's media (Norris et al. 2001) but $<10 \%$ for a Thailand strain grown in CT media containing nitrogen (Li et al. 2001b). Raphidiopsis curvata produces the analog at 2000 times the concentration of CYN ( $\mathrm{Li}$ et al. 2001a). In the current work, cultures for the 10 extracellular and live trials were cultured in ASM1 algal media (Gorham et al. 1964) and were approximately five and six months old, respectively.

Q et al. 2001), but were much higher than those recorded from natural settings. For example, Saker et al. (2004) reported a $\mathrm{Q}_{\mathrm{CYN}}$ value of $0.03 \mathrm{pg}$ cell $^{-1}$ for a Townsville strain of C. raciborskii. Average $\mathrm{Q}_{\mathrm{CYN}}{ }^{-} \mathrm{s}$ in experimental treatments (with snails added) were nearly triple those of the source culture (containing no snails). This could indicate a competitive response by $C$. raciborskii in relation to snail grazing. For example, increased $\mathrm{Q}_{\mathrm{CYN}}{ }^{-} \mathrm{s}$ may lower the palatability of C. raciborskii or increase

20 toxicity: both could be effective in deterring potential grazers. High toxin quotas may also be linked with feeding inhibition: Pereira et al. (2004) demonstrated reduced cell clearance of mussels fed Aphanizomenon issatschenkoi when those cells had high cell toxin content.

\subsection{CYN associated with shell}


M. tuberculata did not bioconcentrate $\mathrm{CYN}$ into shell material $(\mathrm{BCF}<1)$, though small quantities of toxin suggest toxin adsorption to the mantle or shell wall. Possible interaction(s) between $\mathrm{CYN}$ and the proteinaceous and calcareous components of gastropods shells are not known. Thus, bound CYN may have been deposited into the shell, but was unable to be extracted via HPLC/MS-MS. Bioconcentration could take place as the shell layer is secreted from the mantle; however, far longer periods of CYN exposure may be required for this to occur.

\subsection{CYN bioconcentration and bioaccumulation}

CYN accumulation has only been studied in one other freshwater mollusk: Anodonta cygnea mussels recorded maximum CYN values in the haemolymph of $408 \mu \mathrm{g} \mathrm{L}^{-1}$ after fourteen days exposure (Saker et al. 2004). When compared with the total CYN of the surrounding media $\left(90 \mu \mathrm{g} \mathrm{L}^{-1}\right)$, this results in a bioaccumulation factor of 4.53 . M. tuberculata recorded an average BAF value of 49.57 from the whole tissues in similar exposure conditions (Table 7). The higher BAF in M. tuberculata could be attributed to many factors: the studies differed in terms of temperature, C. raciborskii strain, size of test species and toxin extraction methods. Studies of microcystin have demonstrated that mollusks are capable of accumulating this toxin at concentrations

20 from $0.136-630 \mu \mathrm{g} \mathrm{kg}^{-1}$ dry weight (Zurawell 2001; Yokoyama \& Park 2003), which compares with the range of CYN accumulation values reported here (up to $250 \mu \mathrm{g} \mathrm{kg}$ 1, Figure 3).

Bioconcentration and bioaccumulation of $\mathrm{CYN}$ in $M$. tuberculata may have been underestimated since any toxin bound to tissue or metabolized was not measured . Spike recoveries indicating an average recovery of $87.5 \%$ of $\mathrm{CYN}$ are acceptable. 
Equally, bioaccumulation may have been overestimated, since toxins derived from the stomach content of $M$. tuberculata would be included in the total toxin result,. Large proportions of toxins have been reported from the digestive glands of molluscs (Eriksson et al. 1989; Vasconcelos 1995; Saker et al. 2004). Dissection of the alimentary tract prior to analyses could have reduced this problem; however, this was not done since the study was designed to emphasize environmental relevance. That is, making the distinction between 'alimentary tract' and 'rest of the snail' is meaningless, since predators typically consume the entire soft tissues of snails.

10 Considerable variability in tissue toxin concentrations was recorded between the extracellular trials, despite both having identical exposure regimes. The variability of the data could indicate the impact of stress on toxin uptake, metabolism and depuration. For example, additional or synergistic effects (such as poor water quality combined with CYN toxicity) may have resulted in a reduced ability to metabolize toxin. However, only selected samples were analysed for CYN in trial one. The peak toxin value (3267 $\mu \mathrm{g} \mathrm{g}^{-1}$ freeze dried weight) was the average of two samples that had vastly different toxin concentrations (5951 and $583 \mu \mathrm{g} \mathrm{g} \mathrm{g}^{-1}$ ). If these data are discounted, values for trial one compare favourably with those of trial two.

20 The high variability in tissue toxin concentrations recorded during the live trial (Table 7) probably results from the multiple influences on uptake rates. This element of CYN bioaccumulation is also shared with microcystin: previous exposure, differential grazing rates, different snail habitats and the spatial distribution of toxin-laden cells within the water column all contributed to variability in microcystin concentrations of freshwater snails (Prepas et al. 1997; Zurawell et al. 1999). However, in the present 
work, most of these were controlled by the laboratory setting: grazing is thus likely to be the primary cause of variation.

\section{Effects of toxin exposure concentrations and exposure time}

High $\mathrm{CYN}_{\mathrm{TOT}}$ concentrations are likely to result in snails having higher levels of tissue contamination than those in lower-CYN concentration environments. However, overall BAF or BCF values are likely to be similar in both. In contrast, longer exposure times will result in both higher absolute tissue toxin values and significantly increased BAFs, at least where intracellular toxin is present. A significant effect of

10 exposure time was present only during live trial, possibly because tissue harvests were only conducted on days seven and fourteen. Other authors have examined tissue toxin concentrations at two-day or even hourly intervals, and found accumulation and depuration to be highly variable over these timescales (Zurawell 2001; Saker et al. 2004).

\section{Effects of toxin fraction availability}

The difference between bioconcentration and bioaccumulation in M. tuberculata was considerable: exposure to live C. raciborskii culture resulted in far higher toxin loads in M. tuberculata despite $\mathrm{CYN}_{\mathrm{TOT}}$ concentrations being comparable to those used in 20 the extracellular trials. Moreover, intracellular toxin accounted for less than onequarter of total toxin, but led to over $100 \%$ increases in BAFs compared to BCFs. Intracellular toxin therefore appears to be critical in elevating $\mathrm{CYN}$ bioaccumulation values in $M$. tuberculata. Again, this is similar to microcystin accumulation: Prepas et al. (1997) reported that $50 \mu \mathrm{g} \mathrm{L^{-1 }}$ dissolved MC exposure over three days did not result in toxin bioaccumulation in the freshwater clam, Anodonta. In contrast, just 8 
$\mu \mathrm{g} \mathrm{L}^{-1}$ total MC exposure (both cellular and dissolved fractions present) resulted in tissue concentrations of $776 \pm 569 \mu \mathrm{g} \mathrm{kg}^{-1}$ dry weight (Prepas et al. 1997).

CYN exposure concentration strongly impacts the potential for tissue contamination (absolute toxin values, $\mu \mathrm{g} \mathrm{kg}^{-1}$ ) in $M$. tuberculata. Toxin contamination cannot be accurately predicted from exposure concentration alone: length of exposure time and toxin fraction availability must also be considered. Exposure concentrations are also inadequate in predicting the extent of tissue contamination relative to toxins available in the surrounding environment (BCF and BAF values). Rather, these depend more

10 closely on exposure time and, most importantly, the presence of intracellular toxin. In natural blooms, the proportions of dissolved and cell-bound toxins may be highly variable due to algal growth phase, degradation and dilution (Zurawell et al. 1999). Thus, it seems that accurate predictions of bioaccumulation risk cannot be made unless such ratios are properly and regularly quantified, such as in the predictive management approach suggested by White et al. (2005).

\subsection{Deoxy-CYN bioconcentration and bioaccumulation}

Patterns of deoxy-CYN bioconcentration and bioaccumulation were similar to those of CYN, albeit with much lower final tissue concentrations. Deoxy-CYN BAFs were 20 also significantly less than those for CYN. This reflects the fact that deoxy-CYN exposure concentrations were also far lower $\left(0-12 \mu \mathrm{g} \mathrm{L}^{-1}\right)$ than those for CYN $(0-$ $406 \mu \mathrm{g} \mathrm{L}^{-1}$ ). Consequently, exposure to, and accumulation of, deoxy-CYN may be considered less critical to freshwater aquatic organism in comparison to CYN.

\subsection{Possible methods of uptake}


During the extracellular trial, the only possible methods of toxin uptake were transdermal uptake (active or passive transport) or accidental drinking of aqueous toxin. The relative contribution of each of these pathways with respect to final tissue toxin values can only be speculated. Transdermal uptake could result from simple diffusion, where CYN may pass through the cell membranes of the dermisor gill epithelia. Possibly, the protective shell layer may limit transdermal uptake by shielding the fleshy tissues from toxin contact.

The live exposure trial introduced an entirely new route of uptake, since grazing 10 represents an obvious opportunity to ingest large volumes of toxin-laden cells. $M$. tuberculata might graze on C. raciborskii, however gastropods usually graze on attached periphyton. In the natural environment, planktonic C. raciborskii trichomes are uncommon in the benthic habitat of M. tuberculata. On the other hand, snails could consume the filaments that settle out of the water or accumulate in littoral areas during dense blooms. This has already been suggested to occur with Microcystis and Nodularia (Zurawell et al. 1999; Sipiä et al. 2001). Faecal strings of M. tuberculata were not examined for trichomes.

Digestion in freshwater gastropods requires particles to enter via the scraping radula, 20 followed by grinding of material in the gizzard (Dillon 2000). Only particles $\leq 0.4 \mu \mathrm{m}$ are able to pass into the digestive diverticulae, ready for phagocytosis and/or extracellular digestion (Dillon 2000). Based on this evidence, C. raciborskii cells could not leave the alimentary canal without having been lysed, and any toxin present in the cells would become liberated in the alimentary tract. However, intact Microcystis colonies have been reported from the faecal strings of Lymnaea stagnalis, 
indicating that cyanoprokaryote cells could escape the mechanical breakdown performed by the gizzard (Zurawell et al. 1999). Unlike Cylindrospermopsis, however, Microcystis colonies are typically encapsulated in mucilaginous sheaths: these could be crucial in preventing cell (and colony) lysis in the gut (Zurawell 2001).

Given the dramatic increase in bioaccumulation values in conjunction with the introduction of (comparatively) small quantities of cell-bound toxin, grazing is considered to represent the major uptake route. Conversely, extracellular toxin is likely to contribute to only minor tissue contamination. This conclusion is supported

10 by the results of several studies of algal toxin accumulation (Kotak et al. 1996; Prepas et al. 1997; Zurawell et al. 1999; Ozawa et al. 2003; Saker et al. 2004).

\subsection{Implications for management}

Gastropods may form a substantial dietary component of many freshwater and terrestrial species (Dillon 2000). High CYN concentrations in M. tuberculata may indicate the potential for biomagnification of CYN into higher trophic levels, potentially representing a critical issue for human consumption if, for example, commercially important fish predate on CYN-laden snails. This is especially important since CYN and other toxins may persist in the tissues for lengthy time 20 periods. For example, toxins have been detected from organisms some 30 to 65 days after transfer into toxin-free water (Eriksson et al. 1989; Saker et al. 2004).

Ultimately, target setting for protection of aquatic systems will focus primarily on whether or not tissue contamination results in CYN imposing greater ecological risks for aquatic species, or if it causes tissue toxin concentrations to exceed trigger values for human consumption. This study has shown that changes in the relative abundance 
of toxin fractions, rather than overall CYN concentrations, show the most promise in predicting likely CYN bioaccumulation values in $M$. tuberculata.

\section{Acknowledgements}

The authors thank TermiMesh $($ Rockhampton for the donation of stainless steel mesh. This work was supported by Nebo Shire Council (Lake Elphinstone Alliance), the CQU Centre for Environmental Management, the Fitzroy Basin Association, an Australian postgraduate award and federal research training scheme funds. 


\section{Figure captions}

Figure 1. CYN concentrations during trial three (A) total CYN concentrations; (B) extracellular CYN concentrations (controls not tested).

Figure 2. CYN recorded from the shells of $M$. tuberculata following seven days exposure to extracellular toxin.

Figure 3. CYN (expressed as dry-weight equivalent) in $M$. tuberculata: (A) definitive trial one, (B) definitive trial two, (C) definitive trial three. Graphs show average $(n=$ 3 , except in trial one where only selected samples were tested), bars show standard error.

Figure 4. 3-D scatterplot comparing exposure concentration, exposure time, and bioconcentration factors (figure A) or bioaccumulation factors (figure B) for $M$. tuberculata.

Figure 5. Deoxy-CYN in the soft tissues of $M$. tuberculata in (A) definitive trial two (extracellular toxin); and (B) definitive trial three (live culture exposure). Note: treatment deoxy-CYN values not known in definitive trial two.

Figure 6. 3-D scatterplot comparing exposure concentration, exposure time, and bioaccumulation factors for $M$. tuberculata exposure to deoxy-CYN. Controls not included. 
Table 1. Ranges for water quality parameters measured throughout trials. $\mathrm{nt}=$ not tested.

\begin{tabular}{llll}
\hline & $\begin{array}{l}\text { Trial one } \\
\text { (extracellular) }\end{array}$ & $\begin{array}{l}\text { Trial two } \\
\text { (extracellular) }\end{array}$ & $\begin{array}{l}\text { Trial three } \\
\text { (live exposure) }\end{array}$ \\
\hline Illumination $\left(\mu \mathrm{mol}\right.$ photon $\mathrm{m}^{-2} \mathrm{~s}^{-1}$ ) & $60-75$ & $60-75$ & $60-75$ \\
Temperature $\left({ }^{0} \mathrm{C}\right)$ & $25.5 \pm 1{ }^{0} \mathrm{C}$ & $24.5 \pm 1.5{ }^{0} \mathrm{C}$ & $25.0 \pm 1.5^{0} \mathrm{C}$ \\
Alkalinity $\left(\mathrm{mg} / \mathrm{L}\right.$ of CaCo3) ${ }^{\mathrm{a}}$ & 140 & 119 & 110 \\
Hardness $\left(\mathrm{mg} / \mathrm{L}\right.$ of CaCo3) ${ }^{\mathrm{a}}$ & 312 & 357 & 195 \\
$\mathrm{pH}$ & $7.6-8.8$ & $8.0-8.8$ & $7.9-8.9$ \\
Conductivity $\left(\mu \mathrm{S} \mathrm{cm}{ }^{-1}\right)$ & $279-465$ & $85-139$ & $527-873$ \\
DO $(\%$ Saturation) & $\geq 73$ & $\geq 80$ & $\geq 62^{\mathrm{b}}$ \\
Ammonia $(\mathrm{ppm})$ & $0-5$ & $0-2.0$ & $0-1.0$ \\
\hline
\end{tabular}

${ }^{a}$ Control/dilution water, prior to trial; ${ }^{b}$ outliers, values typically $\geq 80 \%$. 
Table 2. CYN concentrations of selected treatment solutions from extracellular trials. Values indicate the CYN concentration of three pooled replicates. nt=not tested; na=not applicable.

\begin{tabular}{ccccccc}
\hline Trial & $\begin{array}{c}\text { Day(s) } \\
\text { since } \\
\text { solution } \\
\text { renewal }\end{array}$ & $\begin{array}{c}\text { Test } \\
\text { concentration } \\
\left(\mu \mathbf{g ~ L}^{-1} \mathbf{C Y N}\right)\end{array}$ & $\begin{array}{c}\text { Actual } \\
\text { concentration } \\
\left(\mu \mathbf{g ~ L}^{-1} \mathbf{C Y N}\right)\end{array}$ & $\begin{array}{c}\text { Percent } \\
(\%) \\
\text { remaining }\end{array}$ & $\begin{array}{c}\text { Actual } \\
\text { concentration } \\
\left(\mu \mathbf{g ~ L}^{-1} \text { deoxy- }\right. \\
\text { CYN) }\end{array}$ & $\begin{array}{c}\text { Deoxy } \\
-\mathbf{C Y N} \\
(\% \text { of } \\
\text { CYN) }\end{array}$ \\
\hline Definitive 1 & 1 & 100 & 100 & 100 & $\mathrm{nt}$ & $\mathrm{na}$ \\
Definitive 1 & 1 & 200 & 250 & 125 & $\mathrm{nt}$ & $\mathrm{na}$ \\
Definitive 2 & 2 & 50 & 31 & 62 & 9.1 & 29 \\
Definitive 2 & 1 & 400 & 336 & 84 & 95.1 & 28 \\
\hline
\end{tabular}


Table 3. Values for CYN toxin fractions in original culture, control and experimental treatments during trial three. $\mathrm{nt}=$ not tested; na=not applicable; $\mathrm{nc}=$ not calculated; and $\mathrm{nd}=$ not detected $(<0.5$ $\left.\mu g \mathrm{~L}^{-1}\right)$.

\begin{tabular}{|c|c|c|c|c|c|c|c|}
\hline \multirow[t]{2}{*}{ Day of Trial } & \multicolumn{7}{|c|}{$\begin{array}{c}\text { Toxin concentrations }\left(\mu \mathrm{g} \mathrm{L}^{-1} \text { or } \% \mathrm{EXC}\right) \\
\text { in experimental treatments }\end{array}$} \\
\hline & Source & Control & $10 \%$ & $20 \%$ & $30 \%$ & $40 \%$ & $50 \%$ \\
\hline \multicolumn{8}{|l|}{$\mathrm{CYN}_{\text {Tот }}$} \\
\hline 0 & 438 & $\mathrm{nt}$ & nt & $\mathrm{nt}$ & nt & nt & nt \\
\hline 2 & 542 & nd & 57 & $5.5^{\mathrm{a}}$ & 184 & 255 & 320 \\
\hline 4 & 420 & nd & 71 & 132 & 210 & 299 & 357 \\
\hline 6 & 714 & nd & 81 & 155 & 213 & 287 & 370 \\
\hline 8 & 631 & nd & 73 & 150 & 209 & 396 & 491 \\
\hline 10 & 985 & nd & 130 & 191 & 227 & 336 & 460 \\
\hline 12 & 879 & 5.8 & 117 & 182 & 264 & 264 & 449 \\
\hline 14 & nt & nd & 110 & 191 & 258 & 223 & 394 \\
\hline Avg \pm std. error & $659 \pm 81$ & na & $91 \pm 10$ & $167 \pm 9^{a}$ & $223 \pm 11$ & $294 \pm 22$ & $406 \pm 24$ \\
\hline \multicolumn{8}{|l|}{$\mathrm{CYN}_{\mathrm{EXC}}$} \\
\hline 0 & 370 & nt & nt & nt & nt & nt & nt \\
\hline 2 & 369 & nt & 46 & 75 & 132 & 181 & 246 \\
\hline 4 & 382 & nt & 61 & 115 & 174 & 232 & 284 \\
\hline 6 & 501 & nt & 67 & 130 & 186 & 236 & 303 \\
\hline 8 & 372 & nt & 64 & 122 & 171 & 293 & 362 \\
\hline 10 & 563 & nt & 84 & 131 & 178 & nt & 331 \\
\hline 12 & 628 & nt & 81 & 133 & 201 & 355 & 354 \\
\hline 14 & nt & nt & 102 & 156 & 230 & 287 & nt \\
\hline Avg \pm std. error & & na & $72 \pm 7$ & $123 \pm 9$ & $182 \pm 11$ & $264 \pm 23$ & $313 \pm 17$ \\
\hline \multicolumn{8}{|l|}{ \% EXC } \\
\hline 0 & 84 & nt & nt & nt & nt & nt & $\mathrm{nt}$ \\
\hline 2 & 68 & nt & 78 & $\mathrm{na}^{\mathrm{a}}$ & 72 & 71 & 77 \\
\hline 4 & 91 & nt & 85 & 87 & 83 & 78 & 80 \\
\hline 6 & 70 & nt & 83 & 84 & 88 & 82 & 82 \\
\hline 8 & 59 & nt & 87 & 81 & 82 & 74 & 74 \\
\hline 10 & 57 & nt & 65 & 68 & 78 & na & 72 \\
\hline 12 & 71 & nt & 69 & 73 & 76 & 134 & 79 \\
\hline 14 & $\mathrm{nt}$ & nt & 93 & 82 & 89 & 129 & na \\
\hline Avg \pm std. error & $72 \pm 5$ & na & $80 \pm 4$ & $79 \pm 3$ & $81 \pm 2$ & $n c^{b}$ & $77 \pm 1$ \\
\hline INC/EXC ratio (average) & $\mathrm{nc}$ & 0 & 0.28 & 0.27 & 0.23 & 0.30 & 0.30 \\
\hline \multicolumn{8}{|l|}{ DEOXY-CYN } \\
\hline 0 & 5.6 & nt & $\mathrm{nt}$ & nt & nt & nt & nt \\
\hline 2 & 6.2 & nd & 0.9 & 0.6 & 5.4 & 6.3 & 8.9 \\
\hline 4 & 11.4 & nd & 2.3 & 3.4 & 5.4 & 9.8 & 11.3 \\
\hline 6 & 19.3 & nd & 2.6 & 3.8 & 5.0 & 9.8 & 10.7 \\
\hline 8 & 7.5 & nd & 1.2 & 1.8 & 2.4 & 9.8 & 12.9 \\
\hline 10 & 26.2 & nd & 4.2 & 5.3 & 7.0 & 3.5 & 13.9 \\
\hline 12 & 9.2 & nd & 3.4 & 5.7 & 9.2 & 8.1 & 14.4 \\
\hline 14 & nt & nd & 3.3 & 7.2 & 7.8 & 5.3 & 12.1 \\
\hline$A v g \pm s t d$. error & $12 \pm 2.9$ & na & $3 \pm 0.5$ & $4 \pm 0.8$ & $6 \pm 0.8$ & $7 \pm 1.0$ & $12 \pm 0.7$ \\
\hline $\begin{array}{l}\text { Average deoxy-CYN } \\
\text { (\%average total CYN) }\end{array}$ & 1.8 & na & 3.3 & 2.4 & 2.7 & 2.4 & 3.0 \\
\hline
\end{tabular}


Table 4. Cell quotas of $C$. raciborskii based on total and intracellular-only $C Y N$ values. $n c=n o t$ calculated.

\begin{tabular}{|c|c|c|c|c|c|}
\hline Treatment & $\begin{array}{l}\text { Cells } \mathrm{mL}^{-1} \\
\text { Average } \pm \text { std error }\end{array}$ & $\begin{array}{l}\mathrm{CYN}_{\text {TOT }} \\
\text { (ng mL } \\
\text { (ng) }\end{array}$ & $\begin{array}{l}\text { Cell quota } \\
\left(\text { pg cell }^{-1}\right)\end{array}$ & $\begin{array}{l}\mathrm{CYN}_{\mathrm{INC}} \\
\left(\mathrm{ng} \mathrm{mL}^{-1}\right)\end{array}$ & $\begin{array}{l}\text { Cell quota } \\
\left.(p g \text { cell })^{-1}\right)\end{array}$ \\
\hline Source day 0 & $1288950 \pm 365203$ & 438 & 0.34 & 68 & 0.05 \\
\hline Source day 4 & $2032575 \pm 26440$ & 420 & 0.21 & 37 & 0.02 \\
\hline Source day 10 & $2118505 \pm 16525$ & 985 & .046 & 421 & 0.20 \\
\hline Source day 12 & $1983 \pm 661$ & 879 & $\mathrm{nc}^{\mathrm{a}}$ & 251 & $\mathrm{nc}^{\mathrm{a}}$ \\
\hline Average & & & 0.34 & & 0.09 \\
\hline $40 \%$ day 2 & $853351 \pm 36355$ & 255 & 0.30 & 73 & .009 \\
\hline $30 \%$ day 4 & $138149 \pm 7271$ & 210 & 1.52 & 36 & 0.26 \\
\hline $40 \%$ day 4 & $521529 \pm 7271$ & 299 & 0.57 & 67 & 0.13 \\
\hline $10 \%$ day 6 & $31992 \pm 529$ & 81 & 2.53 & 14 & 0.44 \\
\hline $30 \%$ day 8 & $409159 \pm 661$ & 209 & 0.51 & 38 & 0.09 \\
\hline $50 \%$ day 8 & $1052642 \pm 47923$ & 491 & 0.47 & 129 & 0.12 \\
\hline $20 \%$ day 10 & $295467 \pm 6610$ & 191 & 0.65 & 61 & 0.21 \\
\hline $30 \%$ day 14 & $120302 \pm 200$ & 258 & 2.14 & 42 & 0.35 \\
\hline Average & & & 1.09 & & 0.21 \\
\hline
\end{tabular}

${ }^{a}$ not calculated due to unexpectedly low cell concentrations. 
Table 5 Variability in data recorded from trial two (extracellular) and trial three (live exposure).Values calculated from group averages per treatment $(n=6)$.

\begin{tabular}{lllll}
\hline & \multicolumn{2}{c}{ Definitive trial two } & \multicolumn{2}{c}{ Definitive trial three } \\
& Week one & Week two & Week one & Week two \\
\hline Average CYN $\left(\mu \mathrm{g} \mathrm{kg}^{-1}\right)^{\mathrm{a}}$ & 406.1 & 475.6 & 48445 & 136446 \\
Average standard deviation & 213.5 & 225.0 & 29981.9 & 105586.1 \\
Average standard error & 123.2 & 129.9 & 17310 & 60960 \\
\% error (std error/average) & 30.3 & 27.3 & 35.7 & 44.7 \\
\hline
\end{tabular}

${ }^{a}$ Freeze-dry weight 
Table 6 Pearson Product Moment Correlations between tissue CYN concentrations and exposure regime. Cells show $p$ value; correlation coefficient; sample size. ns=not significant; $p>0.050$.

\begin{tabular}{lll}
\hline Trial & Exposure concentration & Exposure time \\
\hline Definitive 1 & $\mathrm{p}=0.014 ; 0.685 ; 12$ & $\mathrm{~ns}$ \\
Definitive 2 & $\mathrm{p}=0.000 ; 0.865 ; 36$ & $\mathrm{~ns}$ \\
Definitive 3 & $\mathrm{p}=0.005 ; 0.457 ; 36$ & $\mathrm{p}=0.026 ; 0.363 ; 36$ \\
$\mathrm{CYN}$ TOT & $\mathrm{p}=0.004 ; 0.466 ; 36$ & \\
$\mathrm{CYN}_{\mathrm{EXC}}$ & $\mathrm{p}=0.005 ; 0.460 ; 36$ & \\
$\mathrm{CYN}_{\text {INC }}$ & $\mathrm{p}=0.035 ; 0.352 ; 36$ & \\
$\mathrm{CYN}_{\text {INC }} / \mathrm{CYN}$ EXC ratio &
\end{tabular}


Table 7. Bioconcentration and bioaccumulation factors for CYN-exposed $M$. tuberculata; nd = no data available due to snail deaths. EXC=extracellular only; total=extracellular and intracellular.

\begin{tabular}{|c|c|c|c|c|}
\hline \multirow[t]{2}{*}{ Trial } & \multicolumn{3}{|c|}{ Exposure regime } & \multirow{2}{*}{$\begin{array}{c}\mathrm{BCF}_{\text {or }} \mathrm{BAF}^{\mathrm{a}} \\
\text { (average } \pm \\
\text { standard error) }\end{array}$} \\
\hline & Concentration $\left(\mu \mathrm{g} \mathrm{L}^{-1}\right)$ & Toxin type & Period & \\
\hline \multirow[t]{10}{*}{ Trial one } & 25 & EXC & 7 days & $0^{\mathrm{b}}$ \\
\hline & 50 & EXC & 7 days & $0^{\mathbf{b}}$ \\
\hline & 100 & EXC & 7 days & $0.13^{b}$ \\
\hline & 200 & EXC & 7 days & $1.10^{b}$ \\
\hline & 400 & EXC & 7 days & $1.00^{b}$ \\
\hline & 25 & EXC & 14 days & nd \\
\hline & 50 & EXC & 14 days & nd \\
\hline & 100 & EXC & 14 days & $0.10 \pm 0.10$ \\
\hline & 200 & EXC & 14 days & $0.97 \pm 0.11$ \\
\hline & 400 & EXC & 14 days & $1.48 \pm 0.41$ \\
\hline \multirow[t]{10}{*}{ Trial two } & 25 & EXC & 7 days & $0.43 \pm 0.23$ \\
\hline & 50 & EXC & 7 days & $0.62 \pm 0.16$ \\
\hline & 100 & EXC & 7 days & $0.51 \pm 0.08$ \\
\hline & 200 & EXC & 7 days & $0.48 \pm 0.08$ \\
\hline & 400 & EXC & 7 days & $0.60 \pm 0.15$ \\
\hline & 25 & EXC & 14 days & $0.26 \pm 0.26$ \\
\hline & 50 & EXC & 14 days & $0.64 \pm 0.35$ \\
\hline & 100 & EXC & 14 days & $0.56 \pm 0.14$ \\
\hline & 200 & EXC & 14 days & $0.56 \pm 0.13$ \\
\hline & 400 & EXC & 14 days & $0.66 \pm 0.11$ \\
\hline \multirow[t]{10}{*}{ Trial three } & 91 & Total & 7 days & $39.52 \pm 18.36$ \\
\hline & 167 & Total & 7 days & $49.13 \pm 12.45$ \\
\hline & 223 & Total & 7 days & $33.33 \pm 16.67$ \\
\hline & 294 & Total & 7 days & $54.10 \pm 20.31$ \\
\hline & 406 & Total & 7 days & $43.42 \pm 6.53$ \\
\hline & 91 & Total & 14 days & $49.57 \pm 11.05$ \\
\hline & 167 & Total & 14 days & $120.97 \pm 27.09$ \\
\hline & 223 & Total & 14 days & $124.42 \pm 5.34$ \\
\hline & 294 & Total & 14 days & $98.99 \pm 53.29$ \\
\hline & 406 & Total & 14 days & $109.73 \pm 30.94$ \\
\hline
\end{tabular}


Table 8 Summary results for Pearson Product Moment Correlations between bioconcentration or bioaccumulation values for $M$. tuberculata and experimental conditions. ns=not significant $(p>$ 0.050). Cells contain $p$ value, correlation coefficient and sample size.

\begin{tabular}{|c|c|c|}
\hline Trial & Exposure concentration & Exposure time \\
\hline Definitive $1^{a}$ & $p=0.001 ; 0.861 ; 11$ & ns \\
\hline Definitive $2^{\mathrm{b}}$ & ns & ns \\
\hline Definitive $3^{\mathrm{b}}$ & & $p=0.001 ; 0.582 ; 30$ \\
\hline $\mathrm{CYN}_{\text {TOT }}$ & ns & \\
\hline $\mathrm{CYN}_{\mathrm{EXC}}$ & ns & \\
\hline CYN INC & ns & \\
\hline $\mathrm{CYN}_{\mathrm{INC}} / \mathrm{CYN} \mathrm{EXX}_{\mathrm{EC}}$ ratio & ns & \\
\hline
\end{tabular}


Table 9. Deoxy-CYN bioaccumulation factors for M. tuberculata exposed live C. raciborskii treatments (controls not included).

\begin{tabular}{|c|c|c|}
\hline $\begin{array}{l}\text { Exposure regime } \\
\text { Concentration }\left(\mu \mathrm{g} \mathrm{L}^{-1}\right)\end{array}$ & Period & $\begin{array}{c}\text { BAF } \\
\text { (average } \pm \\
\text { standard error) }\end{array}$ \\
\hline 3 & 7 days & $29.4 \pm 15.85$ \\
\hline 4 & 7 days & $38.4 \pm 1.45$ \\
\hline 6 & 7 days & $31.3 \pm 10.92$ \\
\hline 7 & 7 days & $99.1 \pm 30.94$ \\
\hline 12 & 7 days & $20.4 \pm 9.15$ \\
\hline 3 & 14 days & $249.3 \pm 8.22$ \\
\hline 4 & 14 days & $73.6 \pm 27.64$ \\
\hline 6 & 14 days & $134.2 \pm 27.51$ \\
\hline 7 & 14 days & $66.7 \pm 52.97$ \\
\hline 12 & 14 days & $112.0 \pm 27.69$ \\
\hline
\end{tabular}


Table 10. Pearson Product Moment Correlations between tissue deoxy-CYN concentrations and bioaccumulation factor with exposure regime. Cells contain $p$ value, correlation coefficient and sample size. $n s=$ not significant; $p>0.050$. Controls not included. ns=not significant $(p>0.010)$.

\begin{tabular}{lll}
\hline & Exposure concentration & Exposure time \\
\hline $\begin{array}{l}\text { Tissue toxin concentration } \\
\left(\mu \text { deoxy-CYN kg }{ }^{-1} \text { fresh weight) }\right.\end{array}$ & $p=0.040 ; 0.377 ; 30$ & $p=0.004 ; 0.513 ; 30$ \\
Bioaccumulation factor & ns & $p=0.001 ; 0.556 ; 30$ \\
\hline
\end{tabular}




\section{REFERENCES}

ASTM (2003). E 1192-97 Standard Guide for Conducting Tests on Aqueous Effluents with Fishes, Macroinvertebrates, and Amphibians ${ }^{1}$. American Society for Testing and Materials International, West Conshohocken, Philadelphia, 14p.

Briand J.F., Leboulanger C., Humbert J.-F., Bernard C., Dufour P., 2004. Cylindrospermopsis raciborskii (Cyanobacteria) Invasion at Mid-Latitudes: Selection; Wide Physiological Tolerance, or Global Warming? Journal of Phycology 40, 231-238.

Burkhard L.P., Cook P.M., Mount D.R., 2003. The relationship of bioaccumulative chemicals in water and sediment to residues in fish: a visualisation approach. Environmental Toxicology and Chemistry 22, 2822-2830.

Dillon R.T., 2000. The ecology of freshwater molluscs, Cambridge University Press, Cambridge, UK.

Eaglesham G., Norris K.R., Shaw G.R., Smith M.J., Chiswell R.K., Davis B.C., Neville G.R., Seawright A.A., Moore B.S., 1999. Use of HPLC-MS/MS to monitor cylindrospermopsin, a blue-green algal toxin, for public health purposes. Environmental Toxicology 14, 151-154.

Eriksson J.E., Meriluoto J., Lindholm T., 1989. Accumulation of a peptide toxin from the cyanobacterium Oscillatoria agardhii in the freshwater mussel Anadonta cygnea. Hydrobiologia 183, 211-216.

Fabbro L.D., Baker M., Duivenvoorden L.J., Pegg G., Shiel R., 2001. The Effects of the Ciliate Paramecium cf. caudatum Ehrenberg on Toxin Producing Cylindrospermopsis Isolated from the Fitzroy River, Australia. Environmental Toxicology 16, 489-497.

Gorham P.R., Mc Lachlan J., Hammer U.T., Kim W.K., 1964. Isolation and culture of toxic strains of Anabaena flos-aquae (Lyngb.) de Breb. Verhandlungen. Internationale Vereinigung für Theoretische und Angewandte Limnologie 15, 796-804.

Harada K.I., Ohtani I., Iwamoto K., Suzuki M., Watanabe M.F., Watanabe M., Terao K., 1994. Isolation of cylindrospermopsin from a cyanobacterium Umezakia natans and its screening method. Toxicon 32, 73-84.

Klobucar G.I.V., Lajtner J., Erben R., 1997. Lipid Peroxidation and Histopathological Changes in the Digestive Gland of a Freshwater Snails Planorbarius corneus L. (Gastropoda, Pulmonata) Exposed to Chronic and Sub-Chronic Concentrations of PCP. Bulletin of Environmental Contamination and Toxicology 58, 128-134. 
Kotak B.G., Zurawell R., Prepas E., Holmes C.F., 1996. Microcystin-LR concentration in aquatic food web compartments from lakes of varying trophic status. Canadian Journal of Fisheries and Aquatic Sciences 53, 1974-1985.

Lajtner J., Erbern R., Klobucar G.I.V., 1996. Histopathological Effects of Phenol on the Digestive Gland of Amphimelania holandri Fér. (Gastropoda, Prosobranchia). Bulletin of Environmental Contamination and Toxicology 57, 458-464.

Lam P.K.S., Yu K.N., Ng K.P., Chong M.W.K., 1997. Cadmium uptake and depuration in the soft tissues of Brotia hainanensis (Gastropoda: Prosobranchia: Thiaridae): A dynamic model. Chemosphere 35, 2449-2461.

Li R., Carmichael W.W., Brittain J.E., Eaglesham G.K., Shaw G.R., Mahakhant A., Noparatnaraporn N., Yongmanitchai W., Kaya K., Watanabe M.M., 2001 b. Isolation and identification of the cyanotoxin cylindrospermopsin and deoxycylindrospermopsin from a Thailand strain of Cylindrospermopsis raciborskii (Cyanobacteria). Toxicon 39, 973-980.

Li R., Carmichael W.W., Brittain S., Eaglesham G., Shaw G., Liu Y., Watanabe M., 2001a. First report of the cyanotoxins cylindrospermopsin and deoxycylindrospermopsin from Raphidiopsis curvata (Cyanobacteria). Journal of Phycology 37, 1121-1126.

Mackay D., Fraser A., 2000. Bioaccumulation of persistent organic chemicals: mechanisms and models. Environmental Pollution 110, 375-391.

Nogueira I.C.G., Saker M.L., Pflugmacher S., Wiegand C., Vasconcelos V.M., 2004a. Toxicity of the Cyanobacterium Cylindrospermopsis raciborskii to Daphnia magna. Environmental Toxicology 19, 453-459.

Norris K.R., Eaglesham G., Pierens G., Shaw G., Smith M.J., Chiswell R.K., Seawright A.A., Moore M.R., 1999. Deoxycylindrospermopsin, an analog of cylindrospermopsin from Cylindrospermopsis raciborskii. Environmental Toxicology 14, 163-165.

Norris R.L., Eaglesham G.K., Shaw G.R., Senogles P., Chiswell R.K., Smith M.J., Davis J.A., Seawright A.A., Moore M.R., 2001. Extraction and Purification of the Zwitterions Cylindrospermopsin and Deoxycylindrospermopsin from Cylindrospermopsis raciborskii. Environmental Toxicology 16, 394-396.

Ohtani I., Moore R.E., Runnegar M.T.C., 1992. Cylindrospermopsin: a potent hepatotoxin from the blue-green alga Cylindrospermopsis raciborskii. Journal of the American Chemical Society 114, 7941-7942. 
Ozawa K., Yokoyama A., Ishikawa K., Kumagi M., Watanabe M., Park H.-D., 2003. Accumulation and depuration of microcystin produced by the cyanobacterium Microcystis in a freshwater snail. Limnology 4, 131-138.

Padisák J., 1997. Cylindrospermopsis raciborskii (Woloszynska) Seenayya et Subba Raju, an expanding highly adaptive cyanobacterium: worldwide distribution and review of its ecology. Archiv für Hydrobiologie. Supplement 107 (Monographic Studies) 4, 563-593.

Pereira P., Dias E., Franca S., Pereira E., Carolino M., Vasconcelos V.M., 2004. Accumulation and depuration of cyanobacterial paralytic shellfish toxins by the freshwater mussel Anodonta cygnea. Aquatic Toxicology 68, 339-350.

Prepas E.E., Kotak B.G., Campbell L.M., Evans J.C., Hrudey S.E., Holmes C.F., 1997. Accumulation and elimination of cyanobacterial hepatotoxins by the freshwater clam Anodonta grandis simpsonia. Canadian Journal of Fisheries and Aquatic Sciences 54, 41-46.

Saker M.L., Eaglesham G.K., 1999. The accumulation of cylindrospermopsin from the cyanobacterium Cylindrospermopsis raciborskii in tissues of the redclaw crayfish Cherax quadricarinatus. Toxicon 37, 1065-1077.

Saker M.L., Metcalf J.S., Codd G.A., Vasconcelos V.M., 2004. Accumulation and depuration of the cyanobacterial toxin cylindrospermopsin in the freshwater mussel Anodonta cygnea. Toxicon 43, 185-194.

Schembrii M.A., Neilan B.A., Saint C.P., 2001. Identification of genes implicates in toxin production in the cyanobacterium Cylindrospermopsis raciborskii. Environmental Toxicology 16, 413-421.

Shaw G., Sufenik A., Livne A., Chiswell R.K., Smith M.J., Seawright A.A., Norris K.R., Eaglesham G., Moore M.R., 1999. Blooms of the cylindrospermopsin containing cyanobacterium, Aphanizomenon ovalisporum (Forti) in newly constructed lakes, Queensland, Australia. Environmental Toxicology 14, 167-177.

Sipiä V., Kankaanpää H., Flinkman J., Lahti K., Meriluoto J., 2001. Time-dependent Accumulation of Cyanobacterial Hepatotoxins in Flounders (Platichthys flesus) and Mussels (Mytilus edulis) from the Northern Baltic Sea. Environmental Toxicology 16, 330-336.

Stirling D.J., Quilliam M.A., 2001. First report of the cyanobacterial toxin cylindrospermopsin in New Zealand. Toxicon 39, 1219-1222.

Terao K., Ohmori S., Igarshi K., Ohtani I., Watanabe M.F., Harada K.I., Ito E., Watanabe M., 1994. Electron microscope studies on experimental poisoning in mice induced 
by cylindrospermopsin isolated from blue-green alga Umezakia natans. Toxicon $32,833-843$.

van der Oost R., Beyer J., Vermeulen N.P.E., 2003. Fish bioaccumulation and biomarkers in environmental risk assessment: a review. Environmental Toxicology and Pharmacology 13, 57-149.

Vasconcelos V.M., 1995. Uptake and depuration of the heptapeptide toxin microcystinLR in Mytilus galloprovincialis. Aquatic Toxicology 32, 227-237.

Voutsas E., Magoulas K., Tassios D., 2002. Prediction of the bioaccumulation of persistent organic pollutants in aquatic food webs. Chemosphere 48, 645-651.

White S.H., Duivenvoorden L.J., Fabbro L.D., 2005. A decision-making framework for ecological impacts associated with the accumulation of cyanotoxins (cylindrospermopsin and microcystin). Lakes \& Reservoirs: Research and Management 10, 25-37.

Yokoyama A., Park H., 2002. Mechanism and prediction for contamination of freshwater bivalves (Unionidae) with the cyanobacterial toxin microcystin in hypereutrophic Lake Suwa, Japan. Environmental Toxicology 17, 424-433.

Yokoyama A., Park H., 2003. Depuration kinetics and persistence of the cyanobacterial toxin microcystin-LR in the freshwater bivalves Unio douglasiae. Environmental Toxicology 18, 61-67.

Zurawell R. (2001). Occurrence and toxicity of microcystins in the freshwater pulmonate snail Lymnaea stagnalis. Ph D thesis. Department of Biological Sciences, University of Alberta, Edmonton, Alberta.

Zurawell R., Kotak B., Prepas E., 1999. Influence of lake trophic status on the occurrence of microcystin-LR in the tissue of pulmonate snails. Freshwater Biology 42, 707718.

Zylstra U., 1972. Uptake of particulate matter by the epidermis of the freshwater snail Lymnaea stagnalis. Netherlands Journal of Zoology 22, 299-306. 
Figure 1
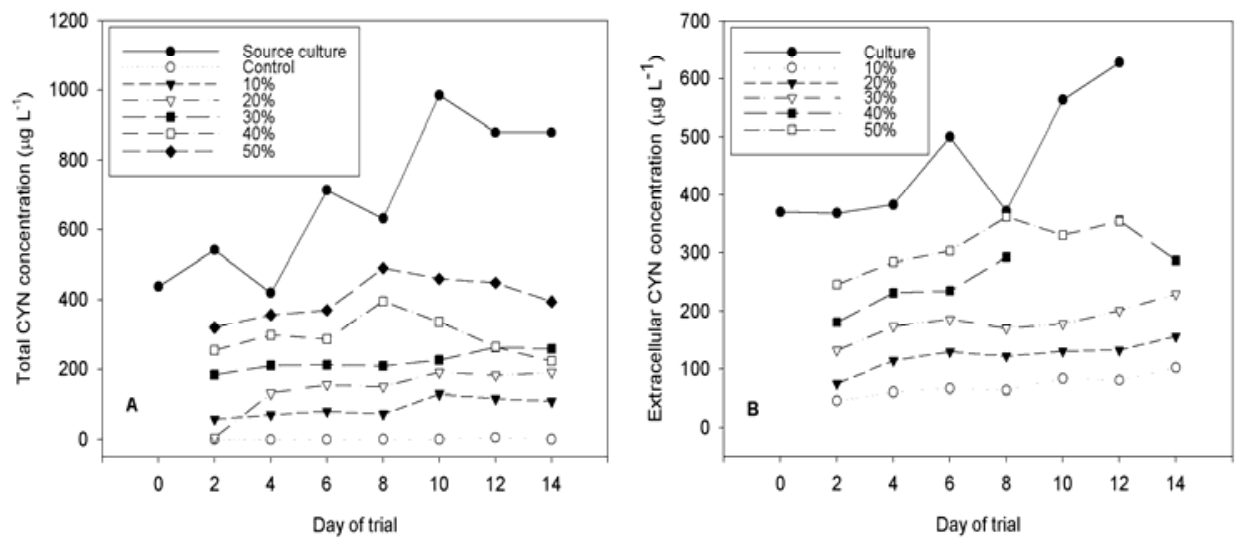

Figure 2

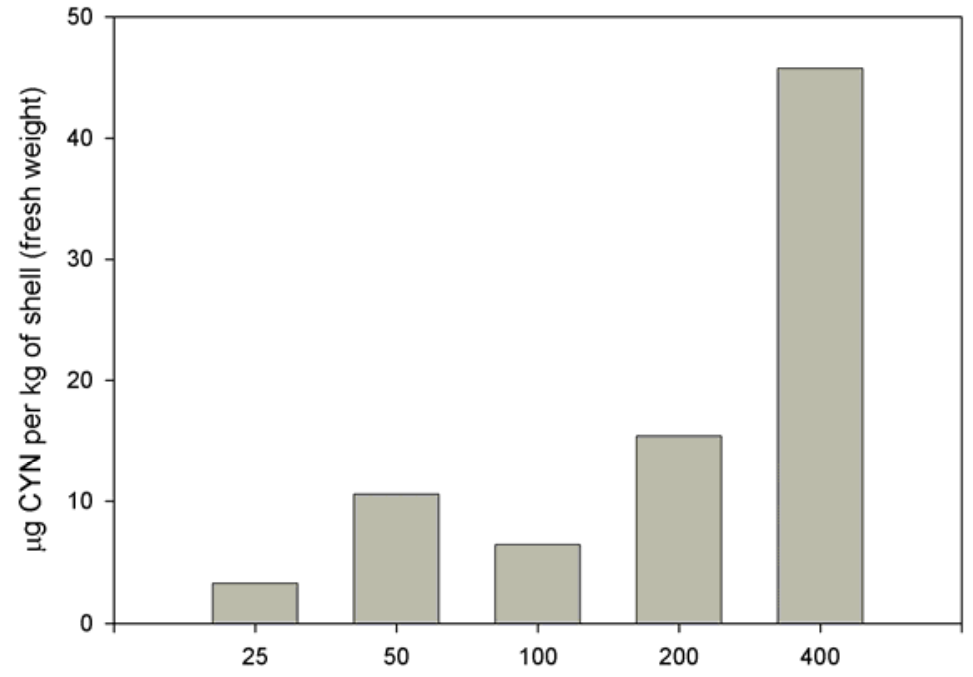

Extracellular CYN exposure concentration ( $\left.\mu \mathrm{g} \mathrm{L}^{-1}\right)$ 
Figure 3
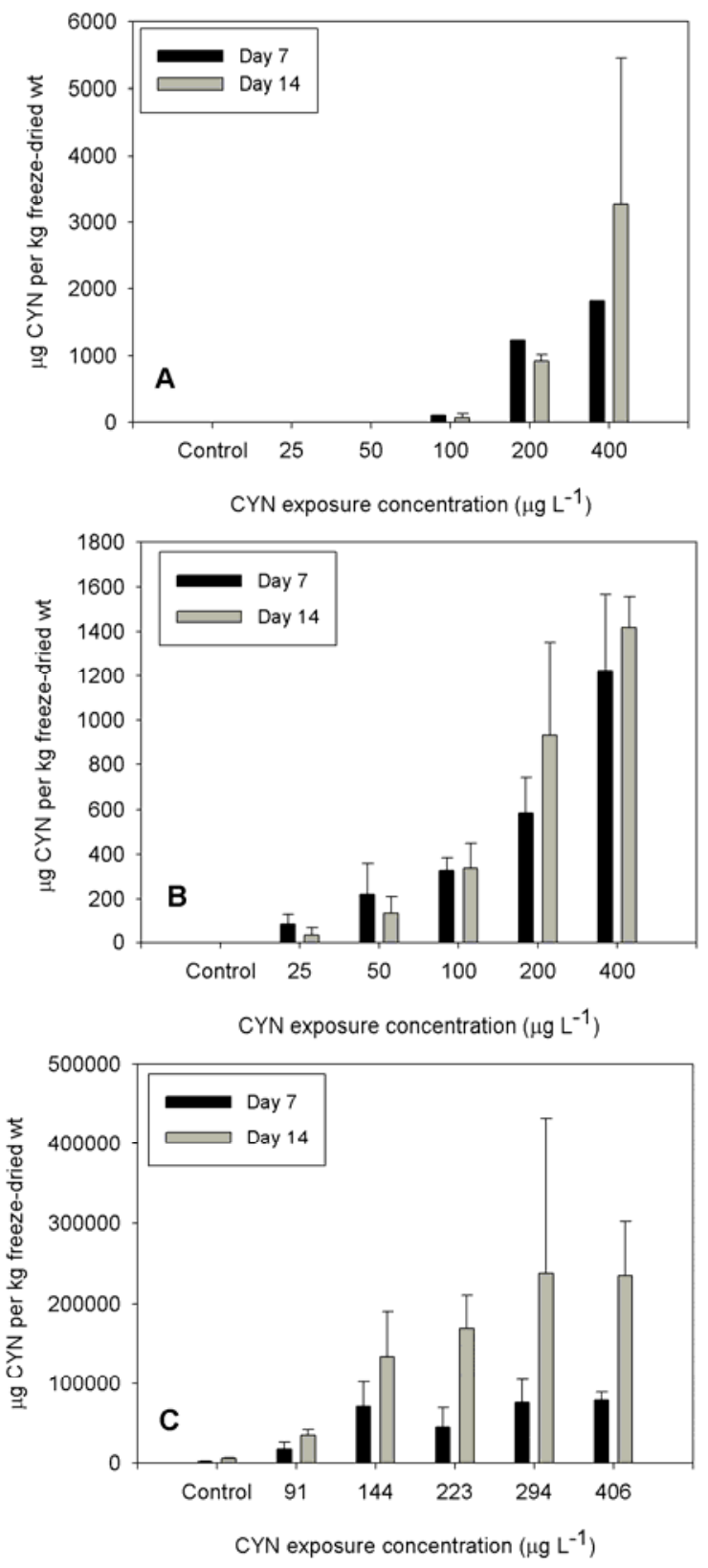
Figure 4
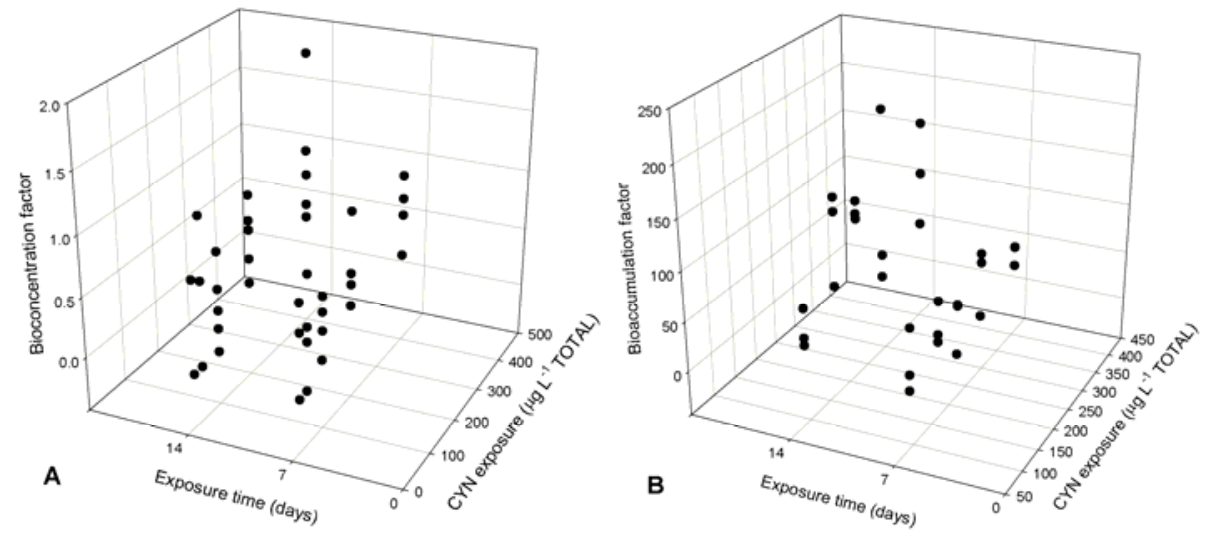

Figure 5

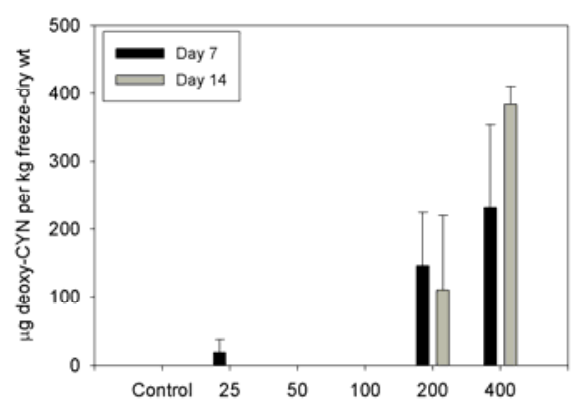

A Extracellular $\mathrm{CYN}$ exposure concentration $\left(\mu \mathrm{g} \mathrm{L}^{-1}\right)$

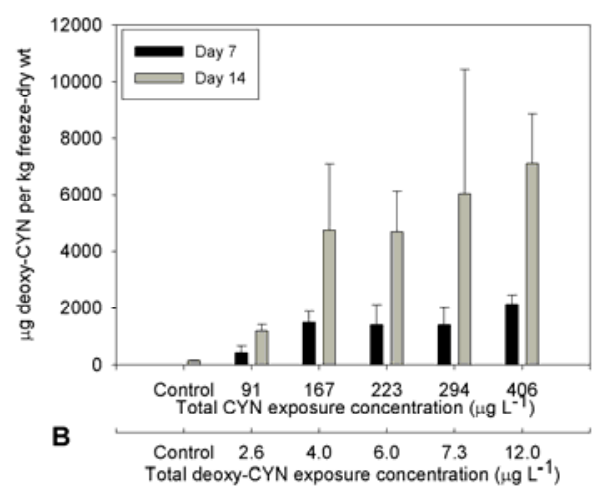

Figure 6

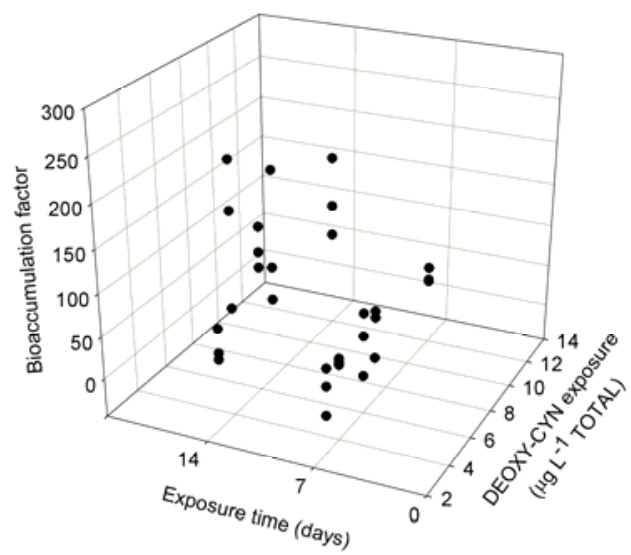

